\title{
VALENTIN LUCAS - SKICA ZA BIOGRAFIJU SLIKARA IZ KRAJA
}

Robert Doričić, mag. admin. sanit. Medicinski fakultet Sveučilišta u Rijeci Katedra za društvene i humanističke znanosti u medicini Braće Branchetta 20, HR - 51000 Rijeka robert.doricic@uniri.hr
UDK 75.07Lucas, Valentin Pregledni članak Primljeno: 3. 6. 2016. Prihvaćeno: 12. 10. 2016 DOI: http://doi.org/ 10.21857/m3v76tzd4y

Carevo rano djetinjstvo i njegovi kasniji posjeti Kraju bili su obilježeni susretima s akademskim slikarom Valentinom Lucasom (1840. - 1915.), koji je ondje živio. Osebujni umjetnik i njegov životni put bio je Caru nadahnuće za likove više literarnih djela, a njemu posvećuje i nekoliko redaka Autobiografije. Polazeći od Careve fikcije i autobiografskih zapisa te zahvaljujući njihovu osvjedočenju u dostupnim povijesnim i drugim vrelima i rezultatima terenskog istraživanja, u ovome se radu nastoji rekonstruirati nedovoljno poznata biografija slikara iz Kraja.

Ključne riječi: Valentin Lucas; slikar; biografija; Kraj; Viktor Car Emin.

\section{Uvod}

Plejadi likova iz književnog opusa Viktora Cara Emina zasigurno su nadahnuća bile brojne osobe koje je umjetnik upoznao za svojega dugoga, ne samo umjetničkoga stvaralaštva već i društveno-političkoga djelovanja. Među njima će jedna ličnost zaokupiti piščevu pažnju već za njegova rana djetinjstva. Nju neće samo posjećivati prilikom odlazaka u Kraj, mjesto svojega dječaštva, već će joj se vraćati i imaginarno, uključujući je u fiktivni svijet zabilježen na stranicama svojih literarnih ostvarenja. No (nesretna) životna i umjetnička sudbina akademskoga slikara iz Kraja, rođenjem Labinjanina, Valentina Lucasa ${ }^{1}$ svoje će mjesto pronaći i na stranicama Carevih autobiografskih zapisa, kojima se književnik posvećuje u zadnjoj

$\overline{1}$ Prezime Lucas u izvorima se bilježi u različitim oblicima (Lucas, Lucaz, Lukac, Lukas). U ovome ćemo radu rabiti onaj oblik prezimena kojim se akademski slikar koristio u korespondenciji i kojim je potpisivao svoje umjetničke radove. 
fazi svojega umjetničkog stvaralaštva. ${ }^{2}$ Prateći na neki način sudbinu samoga Cara Emina, koji je u hrvatskoj povijesti književnosti smatran regionalnim piscem ${ }^{3}$, tako je i slikar Lucas, a osobito njegova biografija, manje poznat hrvatskoj znanstvenoj i široj javnosti.

O životu i umjetničkom stvaralaštvu akademskoga slikara Valentina Lucasa možemo najviše saznati upravo iz pera Viktora Cara Emina. ${ }^{4} \mathrm{Uz}$ to što je slikara osobno poznavao, s njim se i družio, kako u djetinjstvu tako i kasnije, za svojih posjeta Kraju. Car Emin opisao je osobito detaljno Lucasov život u noveli Bez slave $e^{5}$, pa ako bi se tome literarnome djelu i moglo prigovoriti koliko je uistinu njegov sadržaj utemeljen na stvarnim činjenicama, taj argument manje je relevantan za Careva djela autobiografskog karaktera. ${ }^{6}$

S druge pak strane kasnije publikacije i enciklopedijska izdanja iz područja povijesti likovne umjetnosti ${ }^{7}$ koja sadrže informacije o životu i umjetničkome stvaralaštvu Valentina Lucasa donose neprecizne, ponekad nepouzdane, podatke ili su pak oni neažurirani. ${ }^{8}$ Sve to ukazuje na činjenicu da Lucasova biografija nije bila podrobnije istražena ili takvi podaci nisu bili dostupni široj javnosti.

Na temelju arhivske građe i sekundarnih povijesnih vrela, uključujući rezultate terenskoga istraživanja, ovdje ćemo pokušati ocrtati životni put akademskoga slikara Valentina Lucasa, istaknuti pritom njegova umjetnička ostvarenja ${ }^{9}$ na širem libur-

2 Više o tome vidi u: Ines SRDOČ-KONESTRA, Književno djelo Viktora Cara Emina, Adamić, Rijeka; Gradska knjižnica i čitaonica „Viktor Car Emin“, Opatija, 2008.

3

Detaljnije o Carevim književnim ostvarenjima u kojima se koristi likovima inspiriranima ličnošću slikara Valentina vidi: I. Srdoč-Konestra, Književno djelo Viktora Cara Emina, n. dj.

5 Viktor CAR EMIN, Bez slave, Ilustrirani vjesnik, br. 38, br. 39, Zagreb, 1946.

6 Posebno je zanimljiv osvrt Viktora Cara Emina objavljen u autobiografskome radu Iz mog života na činjenicu da je Jadranski institut (danas Zavod za povijesne i društvene znanosti Hrvatske akademije znanosti i umjetnosti u Rijeci) „... uzeo sebi za zadatak, da u stvar nesretnog umjetnika unese što više svijetla. Otpočelo je traganje, a usporedo s time i nastojanje da se vidi koliko ima u onim mojim radnjama istine, a koliko navoda, koje bi trebalo odbiti na autorovu maštu“. Usp. Viktor CAR EMIN, Iz mog života, RAD JAZU, knj. 301, Zagreb, 1954. (poseban otisak), str. 70. Nije nam poznat podatak jesu li ta istraživanja biografije i umjetničkoga rada slikara Valentina Lucasa publicirana. Najljubaznije zahvaljujem na susretljivosti upraviteljici Zavoda za povijesne i društvene znanosti Hrvatske akademije znanosti i umjetnosti u Rijeci (dalje: Zavod za povijesne i društvene znanosti HAZU u Rijeci) dr. sc. Sanji Holjevac prilikom korištenja arhivske građe „Ostavštine Lucas“.

7 Biografske podatke o slikaru Valentinu Lucasu tako primjerice nalazimo u: Kruno PRIJATELJ, Radoslav PUTAR...[et al.], Slikarstvo XIX. stoljeća u Hrvatskoj: katalog izložbe, Galerija slika grada Zagreba "Benko Horvat“, Zagreb, 1961., Boris VIŽINTIN, „Lukas (Lucaz), Valentin“, u: Andre MOHOROVI"ČIĆ (ur.), Enciklopedija likovnih umjetnosti, sv. 3, Inj-Portl, Jugoslavenski leksikografski zavod, Zagreb, 1964., str. 347.; Redakcija, „Lukas (Lucaz), Valentin“, u: Žarko DOMLJAN (ur.), Enciklopedija hrvatske umjetnosti, 1. knjiga, A-Nove, Leksikografski zavod „Miroslav Krleža“, Zagreb, 1995., str. 526-527.

8 To je moguće ilustrirati nepreciznom godinom slikareve smrti ili primjerice neažuriranim podatkom nastalim zbog krađe njegove umjetnine. O oba će slučaja biti više riječi u nastavku.

9 Povijesnoumjetnička analiza stvaralaštva Valentina Lucasa nije tema ovoga rada. Njegove se umjet- 
nijskome ${ }^{10}$ području i nakraju se posvetiti njegovu životnome djelu, koje je nastajalo u Kraju sve do konca njegova života, u vrijeme Prvoga svjetskoga rata.

\section{Potomak labinske građanske obitelji}

Valentin Lucas rođen je u Labinu u prvoj polovici 19. stoljeća. Koncem mjeseca srpnja, 27. srpnja 1840., kanonik Josip (Giusepe) Martinuzzi u labinsku je matičnu knjigu krštenih ${ }^{11}$ upisao da je Valentin Jeronim (Valentino Gerolamo), potomak bračnoga para Lucas, rođen sedam dana ranije, 20. srpnja 1840., u Labinu na kućnome boju $146^{12}$, primio sakrament krštenja. Drugorođeni sin posjednika Valentina ${ }^{13}$ i Gasparine, naslijedivši očevo ime, ujedno je postao predstavnik pete generacije muških članova koji su u tome ogranku labinske građanske obitelji Lucas nosili osobno ime Valentin. ${ }^{14}$ Djetetova majka rođena je u labinskoj obitelji Vellam ${ }^{15}$. Kumovi novorođenca bili su ljekarnik Franjo (Francesco) Millevoj i posjednica Antonija (Antonia) Vellam. Već upis Valentinova krštenja daje naslutiti kako je slikareva obitelj sredinom 19. stoljeća pripadala višem sloju labinskoga društva. ${ }^{16}$ Uporišta tome mo-

nine promatraju u kontekstu biografski relevantnih informacija.

10 Više o značenju pojma Liburnija vidi: Robert MATIJAŠIĆ, „Liburnija“, u: Miroslav BERTOŠA, Robert MATIJAŠIĆ (ur.), Istarska enciklopedija, Leksikografski zavod Miroslav Krleža, Zagreb, 2005., str. 441.

11 „Croatia, Church Books, 1516-1994: Roman Catholic (Rimokatolička crkva) > Labin > Births (Rođeni) 1770-1878“, FamilySearch, https://familysearch.org/pal:/MM9.3.1/TH-1942-28339-9440-38?cc=2040054, preuzeto 28. ožujka 2016.

12 Kuća obitelji Lucas nalazila se izvan labinske starogradske jezgre, u današnjoj ulici Paola Sfecija (k. br. 1). Zahvaljujem na informacijama o obitelji Lucas u Labinu gospodi Marijanu Milevoju i Tulliju Voranu.

13 U biografskoj crtici o slikaru Valentinu Lucasu u katalogu izložbe Slikarstvo XIX. stoljeća u Hrvatskoj, B. Vižintin dodaje da je Valentinov otac gostioničar i administrator na imanju Andreja Vellabija (?). K. Prijatelj, R. Putar... [et al.], Slikarstvo XIX. stoljeća u Hrvatskoj: katalog izložbe, n. dj., str. 205. Možemo pretpostaviti da se u navođenju prezimena Vellabi radi o krivu zapisu prezimena labinske posjedničke obitelji Vellam, s kojom je slikarev otac bio povezan i ženidbenim vezama.

14 Iz upisa krštenja slikareva oca punim imenom Valentina-Josipa-Ivana (Valentin-Giuseppe-Giovanni) u knjigu krštenih labinske župe 7. travnja 1801. vidljivo je da je i ime njegova oca Valentin. Iz istoga upisa čitamo da su se tako zvali i preci krštenikova oca, njegov pokojni otac i djed. „Croatia, Church Books, 1516-1994: Roman Catholic (Rimokatolička crkva)> Labin> Births (Rođeni) 1770-1878“, FamilySearch, https://familysearch.org/pal:/MM9.3.1/TH-1971-28339-8488-53?cc=2040054, preuzeto 28 . ožujka 2016.

15 Obitelj Vellam prisutna je u Labinu već u prvoj polovici 17. stoljeća (1620.). Herman STEMBERGER, Labinska povijesna kronika: povijesne skice Kožljaka, Čepića, Kršana, Šumbera, Radničko Sveučilište, Narodni muzej Labin, Katedra labinske republike Labin, Turistički savez Općine Labin, Labin, 1983., str. 75.

Sredinom 19. stoljeća na području ondašnjega gradskoga naselja žive dva slikareva strica. U zajedničkom kućanstvu sa slikarevim stricem Antonijom i njegovom ženom živi dvoje članova posluge. Poslugu ima i obitelj daljnjeg rođaka Josipa Lucasa (Giuseppe Lucaz). U toj obitelji živi i odvjetnik Ivan Lucas (Giovanni Lucaz) (1823. - 1871.). Arhiv Župe Labin, Kutija SA Labin, 6,1, Status Animarum. Zahvaljujem vlč. Milivoju Korenu na susretljivosti i na dopuštenju uvida u građu arhiva Župe Blažene Djevice Marije Labin. 
žemo pronaći već gotovo stoljeće ranije, kad je slikarev predak jedan od predstavnika obrtničkoga sloja labinskoga građanstva.$^{17}$ Unatoč afirmaciji članova obitelji u gospodarskome životu Labina 18. stoljeća, ostaje nepoznanica kad su se i odakle Lucasovi doselili u Labin. ${ }^{18}$

Valentin Gerolamo bio je drugo dijete u obitelji. Prvorođenac Jakov (Giacomo) (1836. - 1906.) bio je svećenik, upravitelj labinske župe, dekan i kanonik Porečke biskupije. Krajem 19. stoljeća bio je ravnatelj labinskoga hospicija (Casa di ricovero).${ }^{19}$ Uspješno se bavio i arhivskim istraživanjima. ${ }^{20}$ Njihova sestra Ivana (Giovanna) (1845. - 1902.) udala se za umirovljenog časnika ${ }^{21}$ Josipa (Josephus) Basadonnu, rodom iz Plomina, i sa svojom je obitelji živjela u roditeljskome domu. Ondje je stanovao i Valentinov šest godina mlađi brat - trgovac Andrija (Andrea) (1846. - 1926.), također sa svojom obitelji. ${ }^{22}$ Njihova sestra Marija (Maria) umrla je 1851. godine u dobi od devet godina, a najmlađi brat Anton Ljudevit (Antonio Luigi) 1859. godine u dobi od šest godina.

S devetnaest godina, 1859., Valentin Lucas upisuje Akademiju lijepih umjetno-

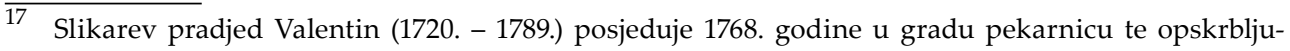
je kruhom i vinom ribare iz talijanske Chioggie, koji ribare u Kvarnerskom zaljevu. MIROSLAV BERTOŠA, Iz ugla povjesničara: toponimi, antroponimi i nadimci u Labinu i Labinštini u drugoj polovici XVIII. stoljeća (Jedno povijesno vrelo iz fonda Vijeća desetorice Državnog arhiva u Mlecima), Folia onomastica Croatica, 12/13, Zagreb, 2003., str. 41-60. U analiziranim arhivskim vrelima o pobuni pučana i labinskih seljaka 1768. spominje se da labinski pekar Valentin Lucaz u listopadu te, 1768. godine ima 49 godina. Isto, str. 51. Međutim prema upisu u labinsku maticu rođenih Valentin (Valentin Domenico) rođen je 15. rujna 1720. Usp. „Croatia, Church Books, 1516-1994: Roman Catholic (Rimokatolička crkva)> Labin> Births (Rođeni) 1682-1770", FamilySearch, https://familysearch.org/ pal:/MM9.3.1/TH-1971-28339-8488-53?cc=2040054, preuzeto 28. ožujka 2016.

Herman Stemberger navodi da se Valentin Lucas u Labin doselio iz obližnjeg mjesta Gora u 17. stoljeću. Usp. H. Stemberger, Labinska povijesna kronika, n. dj., str. 69. Mjesto Gora (Montagna), danas poznata pod nazivom Gora-Glušići, nalazi se južnije od Labina, na obronku u blizini naselja Salakovci. Nije moguće utvrditi radi li se o Valentinu, izravnome pretku slikara kojega pronalazimo u maticama krštenih kao oca Ivana Marije Lucasa (Giovanni Maria Lucaz) krštenog 12. veljače 1706. (Usp. "Croatia, Church Books, 1516-1994: Roman Catholic (Rimokatolička crkva) > Labin> Births (Rođeni) 1682-1770“, n. dj., preuzeto 28. ožujka 2016.) Marijan Milevoj smatra da se obitelj Lucas doselila u Labin početkom 17. stoljeća iz Furlanije. Usp. Marin MILEVOJ, „Prezimena i nadimci - Labin, Raša, Sv. Nedelja, Pićan, Kršan“, http://www.istrianet.org/istria/genealogy/town/albona/notes1. htm, preuzeto 2. travnja 2016.

19 Usp. Guida generale per Trieste, il Goriziano, l'Istria, Fiume e la Dalmazia, Creutz i sur., Trieste, str. 730. Zahvaljujem na ustupljenim materijalima doc. dr. sc. Ivanu Zupancu.

Erneste Nacinovich navodi kako je Jakov Lucas (don Giacomo Lucas) izradio rodoslovlje obitelji Scampicchio za razdoblje od sredine 16. stoljeća do početka 19. stoljeća. Prema: Boris ZAKOŠEK, Analitički inventar arhivskog fonda obitelj Scampicchio (Labin Motovun, Svetvinčenat) 1447-1878 [1882, 1903], Vjesnik istarskog arhiva, sv. 2-3, Pazin, 1992. - 1993., str. 191-121.

21 Usp. „Croatia, Church Books, 1516-1994: Roman Catholic (Rimokatolička crkva)> Labin> Deaths (Umrli) 1861-1910, 1907, 1908“, FamilySearch, https://familysearch.org/pal:/MM9.3.1/TH-1971-2834515455-48?cc=2040054, preuzeto 28. ožujka 2016.

Andrija Lucas vlasnik je trgovine gotove odjeće (Vestiti fatti) i radionice (Manifattura). Usp. i Guida generale, n. dj., str. 731. 
sti u Veneciji (Accademia di Belle Arti di Venezia), gdje studira osam godina ${ }^{23}$ uz pokroviteljstvo brata svećenika. ${ }^{24}$ Još za vrijeme studija, u rujnu 1863., završava danas sačuvani portret školskoga kolege Andrije Bastijanića. Zahvaljujući svojem talentu i predanu radu, Lucas je dobio više nagrada i priznanja koje su uručivane perspektivnim studentima Akademije. ${ }^{25}$

\section{Lucasovo stvaralaštvo u Liburniji}

Nakon završetka studija vraća se u zavičaj i ondje se posvećuje daljnjem umjetničkom stvaralaštvu. ${ }^{26}$ Tri godine nakon završetka studija u Veneciji, 8. svibnja 1870 ., u lovranskoj crkvi sv. Jurja mučenika Valentin Lucas vjenčao se s Katarinom (Catharina) Vervega. ${ }^{27}$ Prema dostupnim lovranskim stališima duša ${ }^{28}$, u prvo vrijeme supružnici žive u Lovranu. ${ }^{29}$ No Katarina se seli u Kastav, gdje postaje prva učiteljica novoosnovane kastavske Djevojačke učione, pučke škole za djevojke otvorene 1877. godine, gdje će učiteljevati sljedeće tri školske godine. ${ }^{30}$ Sedam godina kasnije podu-

23 Valentin Lucas upisuje se na prvu godinu studija u akademskoj godini 1859./1860., kad pohađa kolegije crtanja (Scuola di ornato ed elementi di figura). U sljedećim godinama nastavlja pohađati kolegij elemenata oblika, a tijekom daljnjeg studija odabire kolegij iz osnova arhitekture (Architettura classe Elementare), akta (Nudo), perspektive (Prospettiva) i slikarstva (Pittura). Valentin živi u blizini Akademije, u četvrti Dorsoduro. Usp. Archivio storico della Accademia, Venezia, Matricole generali degli alunni, Valentino Lucas. Zahvaljujem Chiari Gasparini na poslanim arhivskim podacima.

24 Njegov boravak i studij u Veneciji financijski potpomaže stariji brat Jakov. Usp. K. Prijatelj, R. Putar.. [et al.], Slikarstvo XIX. stoljeća u Hrvatskoj, n. dj., str. 205.

Nakon završetka akademske godine 1862./1863.Valentin Lucas osvaja sljedeće nagrade: $I I^{\circ}$ Accessit per la Classe Inferiore di Disegno della scuola del Nudo; $I^{\circ}$ Accessit per la Classe Inferiore degli Esercizi a Memoria della scuola di Statuaria; Medaglia in Rame per la Copia da Disegni della scuola di Prospettiva. Sljedeće akademske godine, 1863./1864., osvaja ovu nagradu: $I^{\circ}$ Accessit per l'Invenzione Storica in Cartone della scuola di Pittura e Nudo. Usp. Archivio storico della Accademia, Venezia, Matricole generali degli alunni, Valentino Lucas.

26 U to vrijeme, 1868. godine, završava palu s prikazom Majke Božje Karmelske, sv. Alojzijem Grignonom i sv. Šimunom Stockom na lijevom bočnom oltaru u osorskoj katedrali Uznesenja Marijina.

Obitelj Vervega pripadala je krugu lovranskih građanskih obitelji. Katarinin otac Stanislav (Stanislaus) (1802. - 1893.) bio je porezni nadzornik. Obitelj Stanislava i njegove supruge Josipe (Josepha), rođene Mitterenner (1812. - 1860.), vjerojatno zbog Stanislavova posla, često se selila, što zaključujemo po mjestima rođenja njihove djece. Katarinina starija sestra Marija (Maria) (1832./1833. - 1908.) rođena je u Trstu, Matilda (Mathilde) (1841. - 1928) i Katarina (Catharina) (1843. - 1907.) u Klagenfurtu, a brat Adolf (Adolphus) (1849./1850. - 1897.) u Grazu. Njihov brat Rikard (Riccardo), rođen 1847., bankar, dao je 1880. godine postaviti u bočnoj lađi lovranske župne crkve, u blizini oltara sv. Križa, spomen-ploču u sjećanje na majku Josipu. Zahvaljujem prof. dr. sc. Robertu Žiguliću na ustupljenim podacima o pojedinim članovima obitelji Vervega.

28 Stališi duša (Status Animarum) popisi su kućanstava koje su vodili župnici. Uključuju osobne podatke (rođenja, ev. vjenčanja i smrti) svih članova koji žive ili su živjeli u tome istome kućanstvu.

29 V. Državni arhiv Rijeka, Status Animarum Parochiae Lauranensis, 1863. - 1891., k. br. Lovran 73, 124, 57

30 U spomenici kastavske osnovne škole nalazimo podatak da je Katarina Lucas otpuštena 1880. godine. Usp. Vojmir JELUŠIĆ... [et al.] (ur.), Dvije stotine godina rada Osnovne škole u Kastvu: 1770-1970, Osnovna škola Kastav, Kastav, 1970., str. 26, 63. 
čava djecu u lovranskoj pučkoj školi. ${ }^{31}$

Za to je vrijeme njezin suprug - boraveći između njihova lovranskoga doma i ateljea ${ }^{32}$, koji je otvorio u nedalekom mjestu Kraj, kamo će se kasnije i trajno preseliti33 - radio na novim umjetničkim ostvarenjima. Narudžbe za slike stizale su kako od lokalnih crkvenih naručitelja tako i od imućnijih građana. ${ }^{34}$ Osim rada na novim kompozicijama, on restaurira djela starijih majstora po crkvama istarskih gradova. ${ }^{35}$

Lucasova umjetnička djela sačuvana su i na širem liburnijskom području. Osim slike Majke Božje ${ }^{36}$ na oltaru sv. Josipa, u crkvi Majke Božje u Kraju nalazi se i dru-

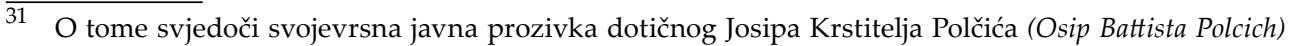
upućena Katarini Lucas, učiteljici u Lovranu, objavljena u listu Naša sloga. Razlog su tomu one škandalozne besede koje ste Vi pravila meni i drugim od moje žene i gospodina učitelja Grosmana. Usp. „Priposlano štovanoj gospoji Katarini Lukas“, Naša sloga, 16. lipnja 1887., 18 (24), str. 4, INO: Istarske novine online, http://ino.com.hr/data/nasa_sloga/1887/24.pdf, preuzeto 4. travnja 2016.

Valentin Lucas otvorio je atelje u obiteljskoj kući u mjestu Kraj, nedaleko od Mošćeničke Drage. Kuća je pripadala Katarininu ocu Stanislavu Vervegi, koji će također živjeti u Kraju, zajedno s drugom suprugom Franciskom (Fransisca), rođ. Marcel. Usp. Državni arhiv Rijeka, Status Animarum DragaKraj; „Croatia, Church Books, 1516-1994: Roman Catholic (Rimokatolička crkva) > Mošćenice> Births (Rođeni) 1821-1888“, FamilySearch, https:/familysearch.org/pal:/MM9.3.1/TH-1942-28345-2945651?cc=2040054, preuzeto 28. ožujka 2016.

Za Valentinom naknadno, nakon službovanja u Kastvu i Lovranu, u Kraj će doći živjeti i njegova supruga Katarina. Ondje će i umrijeti 4. veljače 1907. Matični ured Lovran, Knjiga umrlih župe Mošćenice, 1821. - 1946., str. 343.

Među Lucasovim ostvarenjima koja se nalaze u Labinu ili su postankom vezana za taj istarski gradić postojeća stručna literatura i ona koja tematizira lokalnu prošlost, osim portreta Andrije Bastijanića, izrijekom navodi sliku s prikazom Isusa na Maslinskoj gori, prvotno u crkvi sv. Marije Tješiteljice izvan stare labinske gradske jezgre, a danas u crkvi sv. Franje Asiškog u Podlabinu, koju je Lucas naslikao za vrijeme studija (1862.?), zatim ciklus Križnog puta naslikanog za labinsku župnu crkvu. Usp. Marijan MILEVOJ, Eduard STRENJA, Od crkve do crkve $=$ Da chiesa a chiesa $=$ From church to church: Labin, Raša, Sv. Nedelja, Kršan, Pićan, Matthias Flacius Illyricus, Labin, 1994. U širem labinskom okružju od Lucasovih djela spominju se slika s prikazom Gospe od Milosrđa sa sv. Rokom i sv. Jeronimom (1876.) u barbanskoj župnoj crkvi te oltarna pala s prikazom sv. Katarine (1885.) u svetištu crkve u naselju Sveta Katarina u Pićanštini. Lucasova ostvarenja nalaze se i na području Župe Plomin. U župnoj crkvi Blažene Djevice nalaze se oltarne pale s likom sv. Jurja (1893.) i pala Mater miracolosa (1895.), kao i ciklus Križnog puta. Usp. Marijan BRATOLIĆ, Ivan GRAH, Crkva u Istri: osobe, mjesta i drugi podaci Porečke i Pulske biskupije, III. dopunjeno izdanje, IKD, „Juraj Dobrila, Pazin; Biskupski Ordinarijat, Poreč; „Josip Turčinović“ d.o.o., Pazin, 1999. U filijalnoj crkvi sv. Katarine $\mathrm{u}$ mjestu Zagorje, $\mathrm{u}$ zaseoku Baći, nalazi se oltarna pala s prikazom te svetice. Usp. Marijan MILEVOJ, Eduard STRENJA, Od crkve do crkve = Da chiesa a chiesa = From church to church: Labin, Raša, Sv. Nedelja, Kršan, Pićan, Matthias Flacius Illyricus, Labin, 1994. Osim slika religiozne tematike, sačuvan je i portret krčkog svećenika Antona Kirinčića, a koji se danas čuva u Narodnom muzeju u Labinu. Usp. Narodni muzej Labin, Katalog muzejskih predmeta, inv. ozn. 510:LAB-64. Ovom prilikom zahvaljujem stručnom voditelju Narodnog muzeja u Labinu gospodinu Vedranu Kosu na susretljivosti te na ustupljenim materijalima i informacijama.

Uz postavljanje svojih slika u crkvama Lucas restaurira i djela starih majstora. Tako 1890. restaurira više oltarnih pala u višnjanskoj župnoj crkvi, a dvije godine kasnije primjerice u porečkoj crkvi Gospe od Anđela. Usp. Višnja BRALIĆ, Nina KUDIS BURIĆ, Istria pittorica. Dipinti dal XV al XVIII secolo - Diocesi Parenzo - Pola, Collana degli Atti-n. 25, Unione italiana, Fiume; Universita popolare, Trieste; Centro di Ricerche Storiche, Rovigno, 2005.

Na slici nastaloj 1887. godine prikazana je i panorama naselja Donji Kraj, i to onoga dijela koji se 


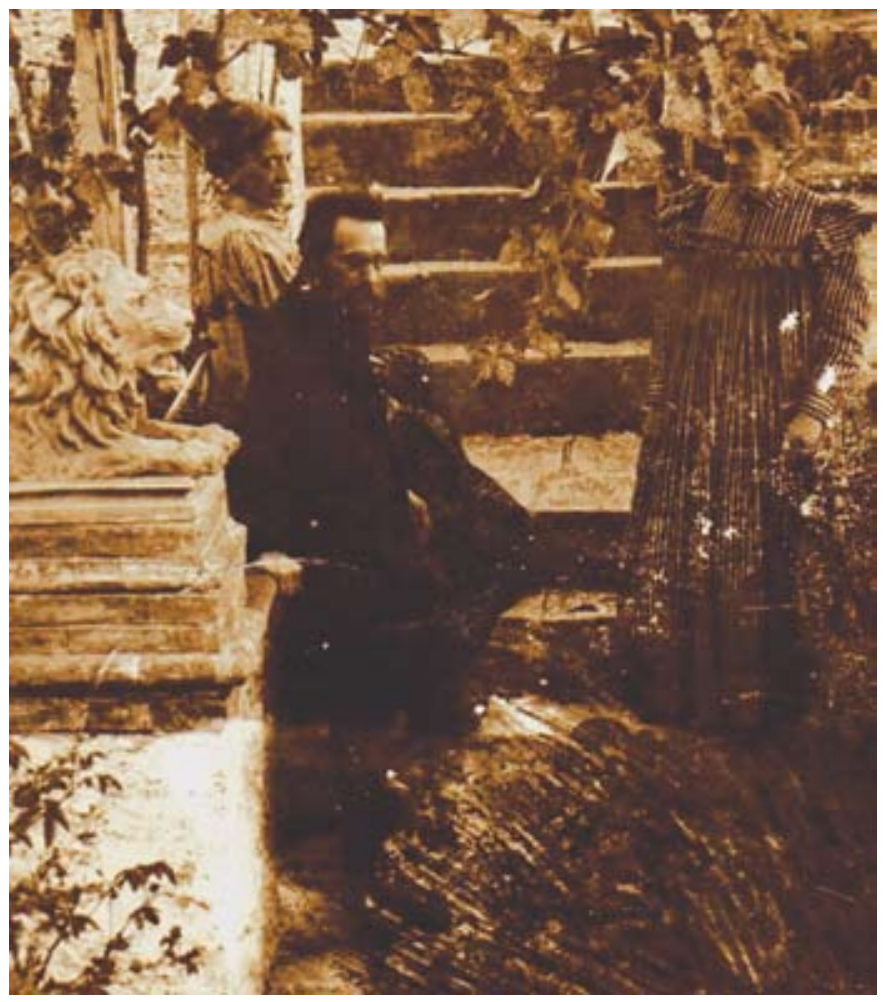

Slika 1. Slikar Valentin Lucas na stubištu koje vodi u njegov atelje u Kraju. Nije poznat podatak tko su ženske osobe na fotografiji, no možemo pretpostaviti da je jedna od njih slikareva supruga Katarina. (Zavod za povijesne i društvene znanosti HAZU u Rijeci, HR-AHAZU-RI-Ostavština Lucas, fotorazglednica, putovala 11. kolovoza 1911., detalj)

ga Lucasova slika. To je ona s prikazom Uskrsloga Krista, koja se nalazi u svetištu, iznad glavnoga oltara.

U susjednoj, lovranskoj župi, u crkvi sv. Roka u Lignju, nalazi se Lucasova slika s prikazom istoimenog sveca na južnom zidu lađe crkve. ${ }^{37}$

No neka djela religiozne tematike naručena za sakralne objekte na liburnijskome području nisu sačuvana.

Osim slike sv. Luke Evanđelista naslikane 1894. godine, drugo, impozantno Lucasovo djelo krasilo je crkvu sv. Luke u Rukavcu. Naime Lucas je ondje 1895.

nalazi ispod županijske ceste Rijeka - Pula. Prema naslikanim stambenim objektima, iznad kojih se ističe toranj na preslicu crkve Majke Božje, može se zaključiti kako je slika nastajala upravo u slikarevu domu/ateljeu, smještenu u istome naselju, no iznad spomenute ceste. 


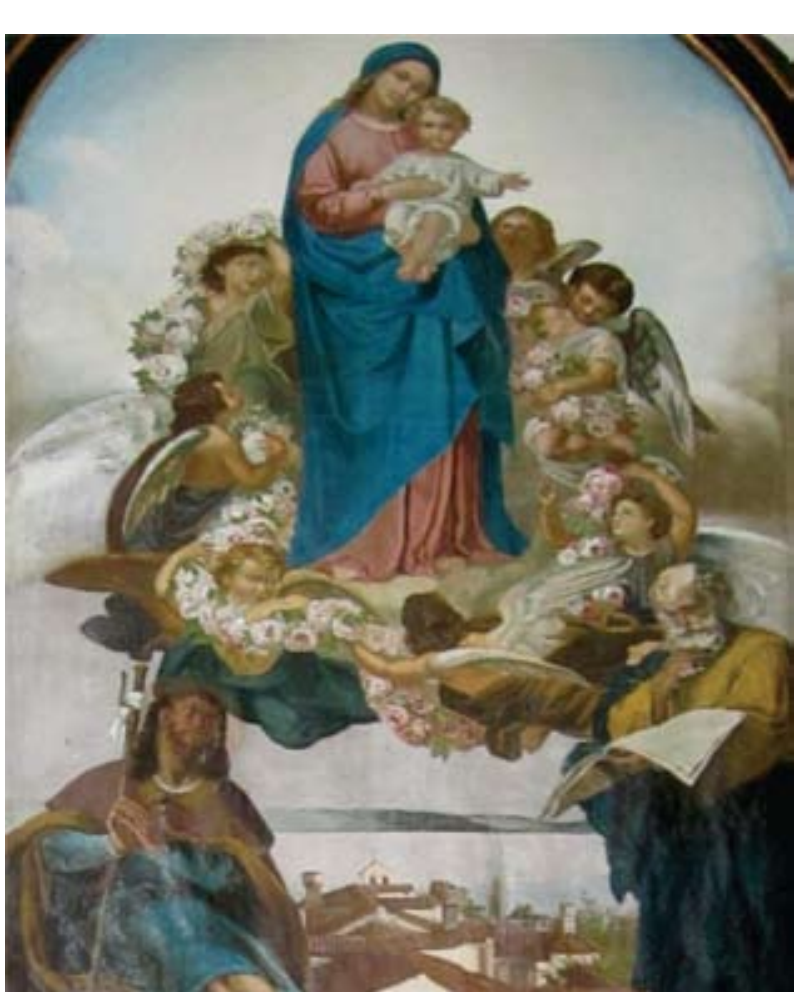

Slika 2. Oltar sv. Josipa. crkva Majke Božje u Kraju, snimila Biserka Doričić, 2010.

godine oslikao strop i gornja polja svetišta. ${ }^{38} \mathrm{U}$ veprinačkoj župnoj crkvi na bočnom oltaru u desnoj bočnoj lađi crkve nalazila se Lucasova slika s prikazom Svete Obitelji. $^{39}$

Valentin Lucas posvećuje se i na području Liburnije portretnome slikarstvu, a jedan se njegov portret čuva u domu lovranske obitelji Marussi. ${ }^{40}$ Nije poznato je li se umjetnik i na tome području bavio restauriranjem slika. ${ }^{41}$

$\overline{38}$ Slika je naručena za vrijeme temeljne obnove i proširenja crkve krajem 19. stoljeća. Usp. Knjižnica Teologije u Rijeci, Josip FRKOVIĆ, Crkve i župe riječke nadbiskupije, sv. II - Opatijski dekanat (rukopis). Zidna slika uništena je 2. listopada 1943. prilikom granatiranja crkve koje je provodila njemačka vojska.

39 Lucasova slika s prikazom Svete Obitelji u župnoj crkvi sv. Marka u Veprincu ukradena je zajedno s nekim drugima umjetninama 1979. godine. Njezina fotografija nije sačuvana. Naknadno je načinjena kopija slike, i to na temelju sjećanja mještana na Lucasov izvornik (Čibej, 2015.). Na informacijama o sudbini veprinačke slike zahvaljujem gospođi Nildi Čibej. U natuknici o slikaru Lucasu u Enciklopediji hrvatske umjetnosti podatak o nestanku slike Svete Obitelji nije ažuriran već se to djelo navodi zajedno s drugim Lucasovim istaknutijim sačuvanim djelima. V. Redakcija, „Lukas (Lucaz), Valentin“, u: Ž. Domljan (ur.), Enciklopedija hrvatske umjetnosti, 1. knjiga, n. dj., str. 526-527.

Portret Matilde Lettis rođene Vervega, koji potpisuje Valentin Lucas, nalazi se u lovranskome domu njezina praunuka gospodina Riccarda Marussija. Matilda Lettis bila je sestra Lucasove žene Katarine. Matildin se sin, pomorski kapetan Ivan (1872. - ?), oženio pak Valentinovom nećakinjom Marčelinom (Marcellina) Lucas (1881. - ?) iz Labina. Obitelj je neko vrijeme živjela u domu Lettisovih u Lovranu. Potomci Lettisovih u Trstu posjeduju još jedan Lucasov ženski portret. Riječ je također o portretu pripadnice te lovranske pomorske obitelji. Zahvaljujem gospodinu Riccardu Marussiju na susretljivosti i ustupljenim informacijama (Marussi, 2015.).

41 Na to ipak upućuje podatak da je prilikom obnove kapele sv. Marine u Mošćeničkoj Dragi, osamdesetih godina 19. stoljeća, dugogodišnji draški crkvenjak Josip Grabrovac predao slikaru Lucasu 


\section{Neobični atelje za neobičnu sliku}

Uza sva djela koja je stvarao, $\mathrm{u}$ jedno od njih Valentin Lucas ulagao je sav svoj kreativni potencijal. Prije negoli se osvrnemo na tu sliku, spomena je vrijedan atelje u kojem je ona bila smještena, a koji Car Emin u svojoj Autobiografiji naziva lijepom i slavnom igračkom. ${ }^{42}$ Naime Valentin Lucas vjerojatno već od sredine sedamdesetih godina 19. stoljeća živi u Kraju. ${ }^{43} \mathrm{Kad}$ je točno sagrađen atelje, koji je bio prislonjen na sjeverni zid obiteljske kuće u vlasništvu Stanislava Vervege, ne zna se pouzdano, no zasigurno je bio zgotovljen početkom devedesetih godina 19. stoljeća, kad Lucas ondje radi na svojemu kapitalnome djelu. Ostaje otvorena mogućnost da je bio sagrađen već za vrijeme nastanka oltarne slike za crkvu u Kraju. Da je zgrada, sagrađena u potpunosti od cigala, bila neobična, osobito u nizu primorskih kuća, spominje i Car Emin u noveli Bez slave. Fasada zgrade u kojoj se nalazio atelje, poznata pod nazivom Vila Minerva, bila je ukrašena ne samo dekorativnim elementima keramičke tvornice iz Wagrama, čiji je vlasnik bio arhitekt Viktor Brausewetter, već i ukrasima koje je moguće pripisati Lucasovu kiparskom izričaju. ${ }^{44}$

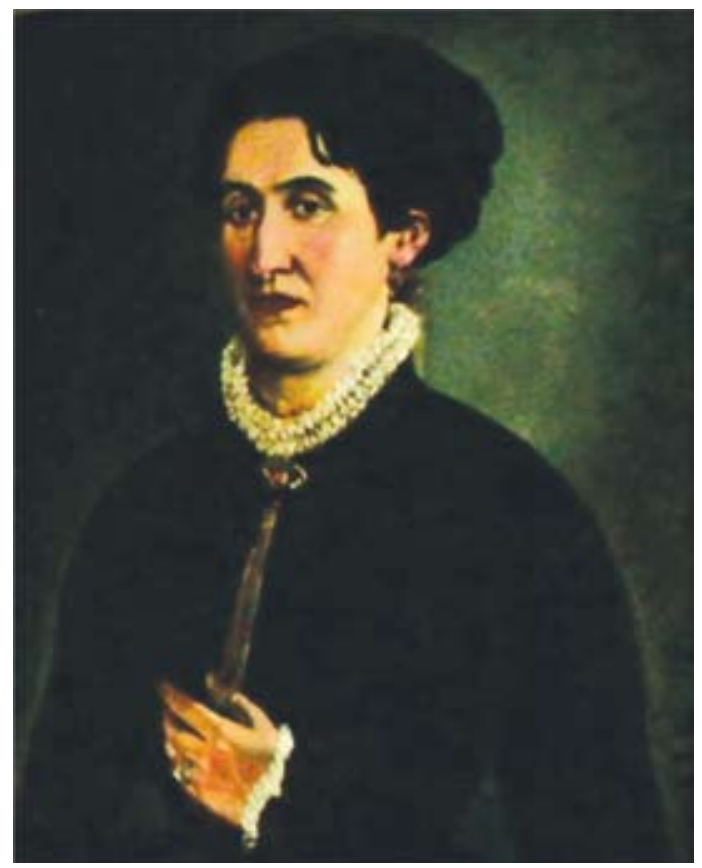

Slika 3. Portet Matilde Lettis rođene Vervega.

Obitelj Marussi, Lovran. Snimio Robert Doričić, 2015.

prvotnu oltarnu palu iz kapele s prikazom sv. Marine, a kojoj se kasnije gubi trag. Usp. Knjižnica Teologije u Rijeci, Viktor PERKAN, Kronika mošćeniške župnije, Mošćenice, 1937., (rukopis), str. 93.

Medaljon s inicijalima „VL“, koji se s visokom sigurnošću može pripisati Valentinu Lucasu, kao nekoliko reprezentativnih dekorativnih elemenata iz Wagrama, primjerice medaljoni s prikazom rimske boginje po kojoj je vila nosila ime, čuvaju se u obiteljskoj kući gospodina Franka Gržina. Ta se kuća nalazi dijelom na mjestu gdje je nekad bio Lucasov atelje. Sačuvana umjetnikova kiparska ostvarenja i keramički dekorativni elementi i danas (2015.), stoljeće nakon slikareve smrti, ispunja- 
U tom je okruženju u neobičnu ateljeu nastajalo životno djelo Valentina Lucasa, kojemu je posvetio četiri desetljeća svojega stvaralačkoga rada, ulje na platnu nazvano Napredak svijeta pred Bogom (Progresso del mondo inanzi Dio). O kakovu se umjetničkome ostvarenju radilo, čitamo, između ostaloga, u drugom izdanju lovranskoga vodiča Eduarda Seisa. Vodič navodi kako u Kraju u svojem ateljeu već 18 godina ${ }^{45}$ slikar Valentin Lucas radi na kolosalnoj slici dimenzija otprilike $100 \mathrm{~m}^{2}{ }^{46}$ Slika prikazuje napredak čovječanstva od stvaranja svijeta do 20. stoljeća. Vodič nadalje opisuje kako je na njoj prikazano više od 2.000 najistaknutijih ličnosti vezanih za religiju, znanost, umjetnost i politiku. Svi se oni okupljaju pod impozantnom pobjedom božanstva u biblijsko-kršćanskom smislu. ${ }^{47}$ Među mnoštvom prikazanih povijesnih ličnosti, ali i Lucasovih suvremenika, na slici su prikazani Judita, Periklo, Atila, Dante Alighieri, Tamerlan (Timur), Ivan Grozni, Nikola Kopernik, Leonardo Da Vinci, William Shakespeare, Ivan Gundulić, Andrija Kačić Miošić, Ruđer Bošković, Napoleon Bonaparte, Giuseppe Garibaldi, Petar Preradović, članovi austrijske i talijanske vladarske kuće i drugi. ${ }^{48}$ Na slici su prikazani i praroditelji Adam i Eva te niz alegorijskih likova, primjerice Dobra i Zla. ${ }^{49}$ Seis dodaje kako se „Neobična slika, za čije potpuno dovršenje daroviti umjetnik daje gotovo svoj čitavi osobni imetak ${ }^{50}$, može pogledati za neznatnu cijenu ulaznice (1 kruna)“.

vaju svoju prvotnu funkciju, a dostupni su i pogledima turista. Zahvaljujem gospodinu Franku Gržinu na gostoprimstvu te ustupljenim informacijama.

Budući da gotovo svi analizirani izvori navode kako je Valentin Lucas na svojoj slici radio puna četiri desetljeća te, ako za godinu izlaska drugoga izmijenjenoga izdanja Seisova vodiča uzimamo 1909. godinu, možemo zaključiti da se period od 18 godina koji se u vodiču spominje odnosi na period od izgradnje ateljea, dakle oko 1891. godine. Usp. Eduard SEIS, Der Sommer- und Winterkurort Lovrana an der österreichischen Riviera und dessen Umgebung, 2. izm. izd., Verlag Franz. J. Schmid, Abbazia, str. 124. i Zavod za povijesne i društvene znanosti HAZU u Rijeci, HR-AHAZU-RI-Ostavština Lucas.

Seis navodi kako se radi o slici čije dimenzije iznose $8 \times 10,5 \mathrm{~m}$. Usp. E. Seis, Der Sommer- und Winterkurort Lovrana an der österreichischen Riviera und dessen Umgebung, n. dj., str. 124.

47

48

u slikarevim suvremenicima s europske političke scene na slici su bili prikazani likovi strijskoga cara Franje Josipa II., austrijske carice Elizabete, talijanskoga kralja Vittorija Emanuelea, kralja Umberta, britanske carice Viktorije i bana Josipa Jelačića. Usp. Zavod za povijesne i društvene znanosti HAZU u Rijeci, HR-AHAZU-RI-Ostavština Lucas, kopija upita Valenta Lucasa poslanoga Općem odjelu za građanstvo u Trstu, 6. listopada 1919. godine; fotoreprodukcija ulja na platnu.

Usp. kopija upita Valenta Lucasa poslanoga Općem odjelu za građanstvo u Trstu, 6. listopada 1919.; fotoreprodukcija ulja na platnu.; V. Car Emin, Djela, n. dj., str. 460, 473.

Sadržaj sačuvanih poštanskih pošiljaka koje Valentin šalje bratu Andriji u Labin upućuje na to da je labinski trgovac financijski potpomagao starijeg brata Valentina. Među njima vrijedi istaknuti pismo koje slikar šalje 12. listopada 1903. na poleđini reprodukcije motiva slike „Napretka“. Ispričavajući se bratu što trenutno $u$ ateljeu nema drugog papira, napominje kako je interesentu koji je voljan kupiti kuću i sliku iskazao načelni pristanak, no i to da će o cijeni i definitivnome dogovoru moći pregovarati sljedeće godine, kad slika bude dovršena. Zanimljivo je istaknuti kako, među ostalim novostima, spominje da u Kraju upravo postavljaju instalacije namijenjene uspostavljanju telefonske veze do nekretnine baruna koji je u Mošćeničkoj Dragi nedavno kupio posjed. Usp. Zavod za povijesne i društvene znanosti HAZU u Rijeci, HR-AHAZU-RI-Ostavština Lucas, pismo Valentina Lucasa poslano brati Andriji, 12. listopada 1903. 

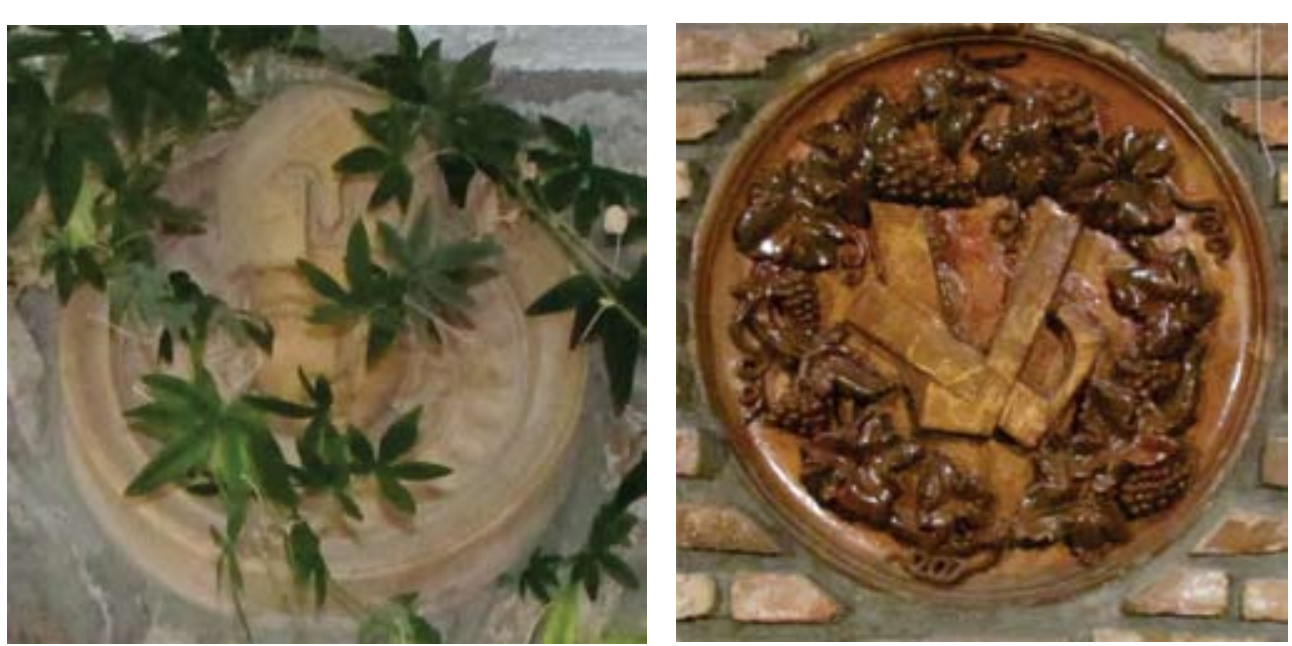

Slika 4. Fasadni dekorativni element s likom božice Minerve (lijevo) i medaljon s inicijalima VL (desno). Obiteljska kuća Gržin, Kraj. Snimio Robert Doričić, 2015.

Unatoč oprečnim stajalištima o vrijednosti toga umjetnikova djela ${ }^{51}$, znatiželjnih posjetitelja koji su dolazili u Kraj, kako čitamo u onodobnim tiskovinama, ali i kasnijim izvješćima, nije nedostajalo. ${ }^{52}$ Svima njima slikar bi dugim štapom pokazivao najvažnije ličnosti koje su prema umjetnikovim kriterijima zavrijedile biti na njoj. Slika je jednako intrigirala opatijske i lovranske turiste aristokratskog porijekla kao i intelektualce, umjetnike i sve druge posjetitelje mjesta Kraj. O brojnosti posjeta svjedoči i sljedeći zapis u Seisovu vodiču: „Interesantan je i umjetnikov album ukrašen brojnim potpisima uglednih ličnosti. ${ }^{\prime 53}$

Među njima u album se, moguće, potpisao i pjesnik Silvije Strahimir Kranjčević (1865. - 1908.). On je posjetio atelje u društvu Viktora Cara Emina. No slikarevo djelo nisu zaobilazili ni stanovnici okolnih naselja. Atelje je posjetila, zajedno s majkom, djevojčica Katarina Lazarić, rođena 1905. godine u zaseoku Grabrova iznad Mošćenica. ${ }^{54}$

51 Tako Car Emin u Autobiografiji piše o impresijama prijatelja koje je vodio da vide sliku: „Svi su se slagali u tome, da umjetnik, kao portretist, zaslužuje hvalu, dok njegovo djelo, kao koncepcija i kompozicija nije prolazilo bez zamjeraka.“ Usp. V. Car Emin, Djela, n. dj., str. 460-461. U nastavku će se istoga teksta autor dotaknuti epizode iz Valentinova života kad je dobio poziv za predstavljanje slike na izložbi u Madridu. Nakon što je sliku pripremio za put, stigla je obavijest u kojoj je otkazano sudjelovanje na madridskoj izložbi. Usp. isto, str. 473.

52 Usp. „La morte d' un pittore“, Il Piccolo della sera, 12. travnja 1915., str. 2; Zavod za povijesne i društvene znanosti HAZU u Rijeci, HR-AHAZU-RI-Ostavština Lucas, Muncipio di Moschienizze, Dichiarazione $N^{\circ} 649$, 16. lipnja 1922. Zahvaljujem Lauri Paris na susretljivosti i poslanome materijalu.

53 Isto, str. 124. Zahvaljujem kolegici Ani Montan na prijevodu s njemačkoga izvornika.

54 Katarina Lazarić udana Senčić svoja sjećanja na posjet ateljeu i sliku prenijela je svojoj kćeri, gospođi Mariji Galović iz Brseča, kojoj zahvaljujem na ustupljenim informacijama (Galović, 2015.). 


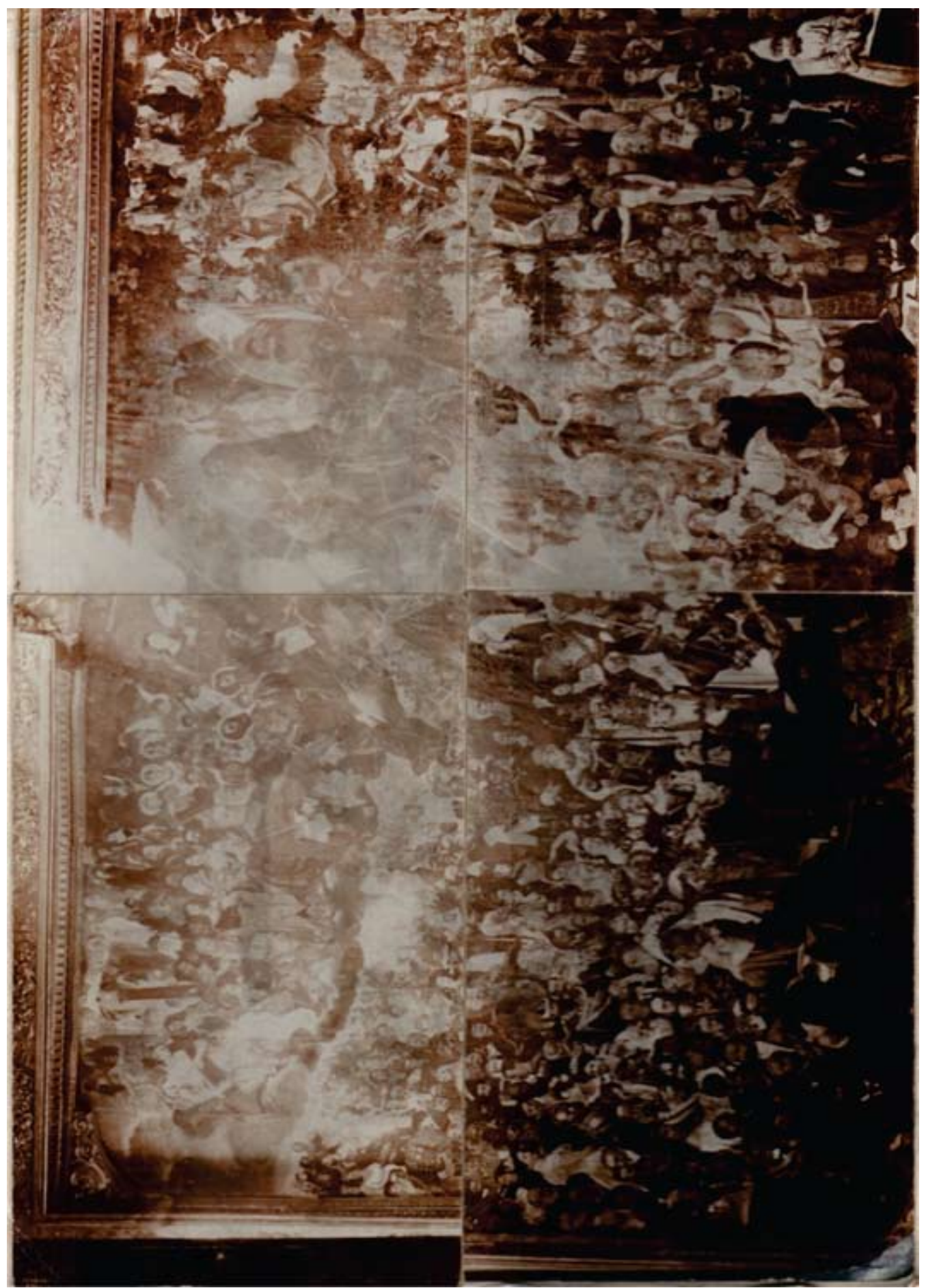


Ni početak Velikoga rata nije prekinuo dolaske posjetitelja, zainteresiranih za atrakciju u Vili Minervi, u Kraj. No ne zadugo jer uvečer 6. travnja 1915., u svojem domu na adresi Kraj 74, umire slikar Valentin Lucas. ${ }^{55}$ Kao razlog smrti mošćenički župnik Ivan Žiganto upisao je gripa (influentia). ${ }^{56}$ Pokopan je dva dana kasnije, 8. travnja, na mošćeničkome groblju. O njegovoj smrti izvijestio je i tršćanski dnevnik Piccolo della sera ${ }^{57}$, odakle vijest prenosi Učiteljski tovariš završavajući obavijest riječima: „Bil je dober portretist i znan cerkveni slikar. Kot človek je bil čudak." ${ }^{\prime 58}$

Valentin Lucas umro je bez potomstva, a njegov je nasljednik postao njegov imenjak $^{59}$ i nećak, liječnik Valente Lucas. ${ }^{60}$ Njemu je, osim umjetnina, pripao atelje, koji već za zadnjeg desetljeća umjetnikova života zahtijeva popravke. ${ }^{61}$ Nakon stričeve smrti nećak neuspješno pokušava zgradi namijeniti funkciju ratnog saniteta ${ }^{62}$,

$\overline{55}$ Enciklopedija likovnih umjetnosti kao i Hrvatska enciklopedija likovne umjetnosti navode tek okvirnu godinu (o. 1914.) slikareve smrti. Usp. B. Vižintin „Lukas Valentin“ u: A. Mohorovičić (ur.), Enciklopedija likovnih umjetnosti, sv. 3, n.dj., str. 347.; Redakcija „Lukas (Lucaz), Valentin“, u: Ž. Domljan (ur.), Enciklopedija hrvatske umjetnosti, n. dj. U katalogu izložbe Slikarstvo XIX. stoljeća u Hrvatskoj stoji pak netočan podatak da je Valentin Lucas umro krajem 19. stoljeća. Usp. K. Prijatelj, R. Putar...[et al.], Slikarstvo XIX. stoljeća u Hrvatskoj, n. dj.

Usp. Matični ured Lovran, Knjiga umrlih župe Mošćenice, 1821. - 1946., str. 410.

Usp. „La morte d' un pittore“, Il Piccolo, n. dj., str. 2.

58 U prijevodu: Bio je dobar portretist i poznati crkveni slikar. Kao čovjek bio je čudak. Usp. „Istrske vesti. Umrl je v Kraju“, Učiteljski tovariš, 23. travnja 1915., 55 (8), str. 4, Digitalna knjižnica Slovenije, http:// www.dlib.si/?URN=URN:NBN:SI:DOC-7R1JAR7S, preuzeto 4. travnja 2016.

59 Radi distinkcije između slikara i njegova nećaka, u tekstu rabimo oblik imena Valente, kako ga u pismima oslovljava slikar.

60 Valente Lucas (1873. - 1932.) bio je četvrto dijete i najstariji sin Valentinova brata Andrije i Marije rođene Signorelli. Nakon završenog studija medicine radi u Beču, Trstu, Puli i Rijeci. U periodu prije Prvoga svjetskoga rata Valente Lucas radio je u Rijeci. U riječkoj medicinskoj povijesti ostat će zapamćen kao prvi specijalist ginekologije, opstetricije i venerologije u gradu. Po povratku u rodni grad 1918. godine politički se angažira i član je Talijanske narodne stranke (Partito popolare italiano). Na temelju izbornih rezultata održanih 22. siječnja 1922. postaje članom Općinskog vijeća Labina (Consiglio communale di Albona). Arhiv Župe Labin, Kutija SA Labin, 6,1, Status Animarum, Zavod za povijesne i društvene znanosti HAZU u Rijeci, HR-AHAZU-RI-Ostavština Lucas, Obavijest o sastavu općinskog vijeća na temelju izbora održanih 22. siječnja 1922., Amir MUZUR, Nezavršena povijest medicine u Rijeci: priča o gradu, ljudima i profesiji, Biblioteka AMHA, Prilozi povijesti zdravstvene kulture, Knjiga 9, Medicinski fakultet Sveučilišta u Rijeci, Hrvatsko znanstveno društvo za povijest zdravstvene kulture, Naklada Kvarner, Rijeka, 2013., str. 101.

61 O tome saznajemo iz sačuvanih poštanskih dopisnica koje slikar šalje bratu Andriji u Labin. Tako primjerice na dopisnici poslanoj 12. rujna 1906. piše kako mu je atelje otkriven te mu kiša pričinja veliku štetu. Iz sačuvanih pošiljki zaključujemo kako je brat Andrija financijski pomagao i popravke na zgradi. Usp. Zavod za povijesne i društvene znanosti HAZU u Rijeci, HR-AHAZU-RI-Ostavština Lucas, pismo Valentina Lucasa poslano brati Andriji, 12. rujna 1906.

62 U odgovoru dobivenom od C. k. namjesništva poslanoga u Pulu u lipnju 1916. Valenteu Lucasu, tada glavnome liječniku 5. poljske satnije 5. pukovnije, stoji kako objekt Vila Minerva nije prikladan za bolnicu Crvenog križa zbog činjenice da Crveni križ nije angažiran u ratnoj zoni, ali i zbog strukturalnih nedostataka zgrade, te upućuje Lucasa da se obrati Državnome konzervatoru u Trstu. Usp. Zavod za povijesne i društvene znanosti HAZU u Rijeci, HR-AHAZU-RI-Ostavština Lucas, pismo Namjesništva Zl. Pol. 787/1-16, 17. lipnja 1916. 
pa Vila Minerva rapidno propada. ${ }^{63}$ Napuštena i derutna, postaje lako savladiva za kradljivce koji iz nje otuđuju umjetnine, ${ }^{64}$ a za njih je interes i dalje postojao. ${ }^{65}$ Unatoč vandalizmu, provalama ${ }^{66} \mathrm{i}$ propadanju zgrade u kojoj je Lucasovo životno djelo bilo smješteno, ono je do kraja Velikoga rata ostalo intaktno. Međutim u veljači 1919., u trećem mjesecu nakon potpisanog završetka rata, i ono će postati meta vojničkoga iživljavanja i destrukcije. Životno djelo Valentina Lucasa pripadnici odreda talijanske 145. pješačke brigade razrezat će na dijelove, motivirani, prema iskazima svjedoka, prikazom austrijskoga cara Franje Josipa II. ${ }^{67}$ Nedugo nakon toga Valente

$\overline{63}$ U obavijesti koju općinski inženjer šalje početkom srpnja 1917. Valenteu Lucasu u pulsku mornaričku bazu stoji kako je iz sigurnosnih razloga, zbog oštećenja stropa dvorane u kući u Kraju, ona morala biti zapečaćena. Isto tako sugerira mu da iz nje premjesti one umjetnine koje još nisu uništene djelovanjem vremenskih neprilika i stoga su pogodne za prodaju. Usp. Zavod za povijesne i društvene znanosti HAZU u Rijeci, HR-AHAZU-RI-Ostavština Lucas, pismo općinskog inženjera Valenteu Lucasu, Zl. 162/17, 3. srpnja 1917. Kako deset godina kasnije Valente Lucas objašnjava u pismu Ministarstvu financija, nakon konzultacija s građevinarima i zbog visokih troškova renoviranja ateljea, odustaje od namjere renoviranja zgrade. Usp. Zavod za povijesne i društvene znanosti HAZU u Rijeci, HR-AHAZU-RI-Ostavština Lucas, pismo Valentea Lucasa Ministarstvu financija, 2. kolovoza 1927.

U izvještaju poslanu iz Uprave žandarske postaje Mošćenice Okružnome sudu u Opatiji 31. prosinca 1917. stoji kako je u periodu 29. - 30. prosinca 1917. iz već napuštene i otvorene Vile Minerva u Kraju nepoznati počinitelj ukrao dvije slike. Od njih je prva, po svemu sudeći, kopija Napretka čovječanstva, opisana visokom otprilike $2 \mathrm{~m}$, na kojima su prikazani likovi austrijskoga carskoga para Franje Josipa i Elizabete, zatim turskog sultana i kralja Nikole iz Crne Gore, Adama i Eve te više drugih osoba. Druga otuđena slika bila je portret pokojnog slikara Valentina Lukasa. Isto tako u izvješću se navodi da čuvarica vile Marija Valentin iz Kraja nije mogla specificirati vrijednost ukradenih umjetnina. Usp. Zavod za povijesne i društvene znanosti HAZU u Rijeci, HR-AHAZURI-Ostavština Lucas, izvješće žandarskog vodnika Priesnika, H. 6/18/1, 31. prosinca 1917.

Andriji Lucasu u pismu datiranu 16. rujna 1918. obraća se s molbom Edmée de Konek Norwall, kći dugogodišnjega riječkoga gradonačelnika Giovannija de Ciotte. U pismu navodi kako je dan prije posjetila Kraj i kuću koja je napola ruševina, no slika Napredak čovječanstva netaknuta je. Gospođa de Konek Norwall zainteresirana je za jednu slikarevu uokvirenu sliku i pozlaćeni okvir. U nastavku piše kako bi voljela imati uspomenu na slikara kojega je još kao djevojčica upoznala. Dodaje da bi bila zainteresirana i za otkup drugih antikviteta ako ih je umjetnik posjedovao. Usp. Zavod za povijesne i društvene znanosti HAZU u Rijeci, HR-AHAZU-RI-Ostavština Lucas, pismo Edmée de Konek Norwall Andriji Lucasu, Villa Edmée, Lovran, 16. rujna 1918.

U svjedočenjima čuvarice vile Marije Valentin, udane Cal, i mještana Kraja Marije Sandalj, Josipa (Giuseppe) Marcela, Ane Sandalj, Ane Prušić (Prussich), Milana Keršula, postolara Jurja (Giorgio) Sandalja (Sandali), primalje Marije Keršul i predstavnika seoske zajednice Ivana (Giovanni) Rahtelija zabilježeno je kako su i za vrijeme rata austrijski vojnici i grupe talijanskih vojnika provaljivali u zgradu te odnosili slike i kipove, a drvo stepenica (slikarske?) skale rabili za ogrjev. Usp. Zavod za povijesne i društvene znanosti HAZU u Rijeci, HR-AHAZU-RI-Ostavština Lucas, izjava mještana Kraja, 27. siječnja 1921.

Vidjevši lik cara Franje Josipa II., vojnik je bajunetom probio sliku, a nakon toga su i ostali počeli s uništavanjem slike, izrezujući s nje najljepše prikaze glava i likova te ih uzimajući sa sobom. Usp. Zavod za povijesne i društvene znanosti HAZU u Rijeci, HR-AHAZU-RI-Ostavština Lucas, kopija upita Valenta Lucasa poslanoga Općem odjelu za građanstvo u Trstu, 6. listopada 1919. U sačuvanoj izjavi svjedoka, onoj Antonija Petranića (Petranich), Crešanina koji je u to vrijeme živio u Mošćeničkoj Dragi, spominje se kako je pritom uništena još jedna slika, na kojoj je prikazan motiv iz rimske legende o smrti plebejke Virginije. Usp. Zavod za povijesne i društvene znanosti HAZU u Rijeci, HR-AHAZURI-Ostavština Lucas, izjava svjedoka Antonija Petranića (Petranich), Labin, 29. ožujka 1920. 
Lucas započinje dugotrajnu osmogodišnju borbu s resornim ministarstvima tražeći odštetu za uništenje naslijeđene umjetnine ${ }^{68}$, no - sudeći prema dostupnoj dokumentaciji - odšteta nije nikad dodijeljena. ${ }^{69}$

O daljnjoj sudbini derutne Vile Minerve saznajemo iz Carevih autobiografskih zapisa. ${ }^{70}$ Nakon uništenja slike u poratnim je godinama s ruševne zgrade skinuta $i$ prodana opeka. Od zgrade su ostali sačuvani tek fragmenti bogate dekorativne fasadne plastike, tragovi u dvorištu kuće budućih vlasnika imanja kao i oni na bočnome zidu starinske kuće na koju je neobična zgrada bila dograđena. Ostaci ateljea na bočnom zidu starinske kuće bili su vidljivi sve do njezine rekonstrukcije početkom devedesetih godina 20. stoljeća.

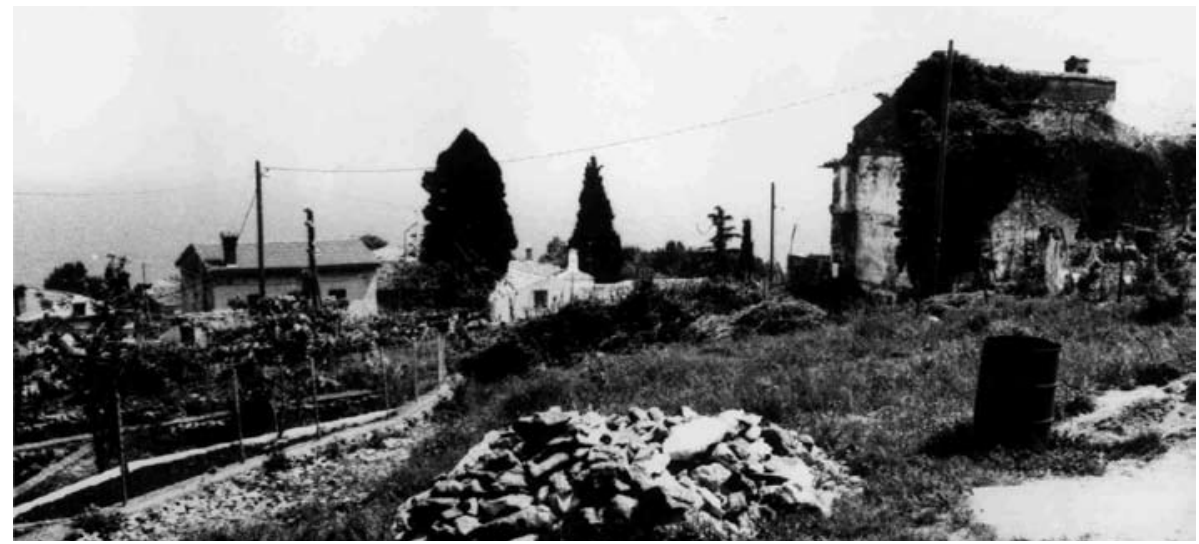

Slika 6. Ostaci ateljea Valentina Lucasa vidljivi na bočnome zidu kuće (na slici desno) i pogled na dio naselja Kraj ispod županijske ceste Rijeka - Pula. Fototeka Konzervatorskoga odjela u Rijeci, snimio V. Malinarić, 1985.

$\overline{68}$ Iz pisma poslana Ministarstvu financija Kraljevine Italije Valente Lucas jasno ističe da je on još za života svojega strica financijski potpomagao rad na njegovu životnome djelu, a ujedno navodi kako je stric živio u skromnim uvjetima, trošeći svu svoju zaradu od prodaje slika na materijal za svoje životno djelo. Usp. Zavod za povijesne i društvene znanosti HAZU u Rijeci, HR-AHAZU-RI-Ostavština Lucas, izjava mještana Kraja, 27. siječnja 1921.

69 Prema zadnjem datiranom dokumentu (22. prosinca 1927.) iz ostavštine Valentea Lucasa, a koji se odnosi na odgovor na zahtjev za odštetu, saznajemo kako se Ministarstvo rata Kraljevine Italije ne smatra odgovornim za počinjenje štete koju su učinili talijanski vojnici. Usp. Zavod za povijesne i društvene znanosti HAZU u Rijeci, HR-AHAZU-RI-Ostavština Lucas, odgovor Ministarstva rata Kraljevine Italije, 22. prosinca 1927. Nije poznato je li Valente Lucas nakon toga pa sve do svoje smrti 1932. godine nastavio sa zahtjevima za odštetom ili je to činio njegov brat Jakov (Giacomo) Lucas (1879. - 1953.) iz Labina, ujedno i zadnji pripadnik tog ogranka obitelji Lucas. On je nakon smrti brata Valentea postao nasljednik stričeve imovine. Usp. Ljetopis Jugoslavenske akademije znanosti i umjetnosti: Za godinu 1954., knj. 61, Izvještaj o radu Jugoslavenske akademije znanosti i umjetnosti za 1953. godinu, str. 51, dostupno na: http://dizbi.hazu.hr/?object=list\&rr[7][o][2544]=o, preuzeto 10. travnja 2016.

Usp. V. Car Emin, Djela, n. dj., str. 473. 


\section{Na kraju}

Možemo se nadati, a to je dijelom i intencija ovoga rada ${ }^{71}$, da će predstavljeni segmenti biografije Valentina Lucasa potaknuti daljnji znanstveni interes za toga nedovoljno poznatog umjetnika i njegovo stvaralaštvo među stručnjacima različitih profila.

S druge pak strane, vrijedi vjerovati kako je priča o neobičnom slikaru i njegovu još neobičnijem životnom djelu kuriozum koji može s punim pravom biti uključen u kulturno-turističku promidžbu Kraja, ali i šire regije. Na tragu one prakse kako je to prije stotinu godina činio i Eduard Seis.

Na koncu ostaje pitanje trebamo li se onda složiti s Carevom završnom rečenicom u noveli Bez slave: „A malo selo ostalo opet sa onih svojih petnaest starih kućica, samo i bez slave." Mišljenje je autora da je to, kad je o spomenutome mjestu riječ, zahvaljujući Viktoru Caru Eminu, a nadajmo se ponovo i zbog Valentina Lucasa, daleko od istine.

\section{Robert Doričić}

\section{Valentin Lucas - Biographical Sketch of the Painter from Kraj}

\section{Summary}

Viktor Car Emin's early childhood and his later visits to Kraj have been characterised by meetings with academic painter Valentin Lucas (1840-1915), who lived there. The distinctive artist and his life inspired Car in creating several characters in his literary work. Additionally, Car dedicated a few lines in his autobiography to him. Starting from Car's fiction and his autobiographical notes and their verification in the available historical and other sources, as well as from the results of field research, this paper tries to reconstruct unknown details in the biography of the painter from Kraj.

Keywords: Valentin Lucas; painter; biography; Kraj; Viktor Car Emin.

$\overline{71}$ Zahvaljujem Viviani Brkarić, Branki Dubravica, dr. sc. Ivani Eterović, Irmi Ferenčak, Mateji Fumić, Editi Jeličić Krpan, vlč. Bernardu Jurjeviću, vlč. Ivanu Katunaru, dr. sc. Lidiji Nikočević, vlč. Đuri Puškariću, Ernesti Topić, Zdenki Zorica i svima onima koje sam slučajnim, nenamjernim propustom izostavio spomenuti, a koji su ovo višegodišnje istraživanje svojom susretljivošću i angažmanom učinili ugodnijim i tako me dodatno motivirali da svojim radom pokušam pridonijeti boljem poznavanju životnoga puta slikara Valentina Lucasa. 